\title{
FORMATION OF RESEARCH COMPETENCE OF FUTURE MUSIC TEACHERS BY MEANS OF INTERACTIVE TECHNOLOGIES
}

\author{
Kulikova S. V., Zotova V. E.
}

\section{INTRODUCTION}

The transformations taking place in the system of higher education are due to the dynamic movement towards an innovative personaldevelopmental educational paradigm, the need to use the intellectual and creative potential of the individual to carry out conscious activities in all spheres of life.

Solving this problem requires a review of the objectives and content of training. New generation standards as planned learning outcomes require mastery of universal learning activities, namely: personal, regulatory, cognitive, communicative, which, in turn, will ensure their mastery of cultural identity, social competence, ability to creative search and creative thinking, the desire to self improvement. In today's conditions of transformational changes in all spheres of the Ukrainian state, the professional training of the future specialist is a leading factor in its social and economic progress. It is acknowledged that in modern society the greatest value and main asset belongs to a specialist who is able to find and assimilate new knowledge, make non-standard decisions, an extremely important area of pedagogical science is the search for tools and conditions to improve the training of specialists in higher education of all the profiles, including future music teachers.

Training of future specialists in a fundamentally new format in the direction of reforming higher education in Ukraine is regulated by the Law of Ukraine "On Higher Education" (2014), the Concept "New Ukrainian School" (2016), the Law of Ukraine "On Education" (2017), the State National Program "Education" ("Ukraine of the XXI century"), the Concept of development of continuous pedagogical education, the National doctrine of development of education of Ukraine in the XXI century, the National strategy of development of education in Ukraine for the period till 2021 and other regulatory documents. In the context of increasing attention to the training of future professionals 
outlines the special urgency of the problem of professional competence of future music teachers, which includes the ability of individuals to acquire knowledge and skills in art education institutions, to form personal qualities and values and value orientations required for professional activity according to social requirements. The level of development of professional competence of a music teacher reflects the degree of his readiness for music-educational work in a secondary school, it is a prerequisite for the effectiveness of pedagogical activities, a kind of link to improve intellectual and practical experience, finding effective ways to improve pedagogical skills.

One of the effective and relevant ways to develop the professional competence of a music teacher in general and research competence in particular, are interactive technologies. In accordance with the Law of Ukraine "On Education" and the requirements of the competence approach, mastering interactive technologies has become one of the main conditions for teaching art subjects by teachers of secondary schools. A number of authors note that as a result of the use of interactive technologies there is an actualization of intellectual reserves and capabilities of students, replenishment of theoretical and generalizing knowledge, deepening and expanding the individual semantic context in working with educational material.

In the scientific literature on the problem of research, educational competence was understood mainly in works on the problem of pedagogical activity - I. Bekh, I. Zyazyun, A. Markova, O. Ovcharuk, O. Pekhota, S. Sysoeva, etc.; partly it was investigated in works devoted to the issues of professional training of future music teachers. In particular, the essence of pedagogical activity of a music teacher was considered by E. Abdulin, G. Didych, V. Orlov, O. Oleksyuk, A. Kozyr, G. Padalka, O. Rostovsky, O. Rudnytska, O. Shcholokova and others; mastering musical and pedagogical knowledge - G. Padalka, O. Rostovsky, O. Rudnytska, O. Shcholokova, etc.; The problem of competence education was paid attention to in their works by such Ukrainian scientists as I. Bekh, I. Yermakov, I. Zyazyun, M. Knyazyan, V. Luhovy, L. Masol, O. Ovcharuk, O. Oleksyuk, V. Radul, V. Cherkasov, O. Shcholokova and others.

In recent years, a number of scientific papers have appeared, which emphasize the importance of music teachers' research skills (L. Archazhnikova, R. Verkholaz, S. Grozan, L. Isayeva, I. Nemykin, L. Pichugin, V. Stolyarov, V. Cherkasov and others). Researchers also pay attention to the use of interactive technologies in music and 
pedagogical activities. We should mention the scientific investigations of I. Zabolotska, V. Zotova, A. Markov, L. Romanenko, and others.

But many aspects of the problem of forming the research competence of the future music teacher with the use of interactive technologies have gone unnoticed by researchers, for example, its content and structure, diagnostic possibilities, methods and technologies of formation, etc. have not been disclosed.

\section{Research competence of the future teacher of music art}

The new paradigm of art education in the XXI century transforms the modern educational space, focusing on individualization of differentiation, alternative and variable educational systems that adapt to changes in the socio-economic environment and to the rapid growth of scientific and technological progress in the world. Modernization of forms, methods and content of the educational process in art education institutions is an urgent need, and the process of reforming this branch is a driver that accelerates significant changes in the educational process and is based on a competency-based approach using the latest technologies in music pedagogy. Interactive new technologies in music education open to students and teachers a wide range of opportunities for both methodological-practical, and research activities.

The learning process, based on the use of interactive teaching methods, is organized with the account of involvement of all participants in the learning process. Joint activity means that everyone makes a special individual contribution, during the lesson there is an exchange of knowledge, ideas, methods of activity. Individual, pair and group work is organized, project activities, role-playing games are used, work with documents and various sources of information is carried out.

According to L. Archazhnikova, a creative, research approach to the process of teaching music is embedded in the very specifics of the teacher-musician, which integrates the implementation of pedagogical, vocal, choir, musicological, performing and research functions. Thus research quest represents the highest stage of creativity of the teacher ${ }^{1}$. In pedagogical activity, the research component is manifested in the identification of contradictions that reduce the effectiveness of the work; formulation of a pedagogical problem; conducting a critical analysis of pedagogical facts and phenomena; studying them in development,

\footnotetext{
${ }^{1}$ Арчажникова Л.Г. Профессия - учитель музыки. Москва : Просвещение, 1984. $111 \mathrm{c}$.
} 
establishing causal relationships; ability to make reasonable conclusions and generalizations based on the results of pedagogical activity; search and creation of original forms, methods of organization of musical activity of students; tracking the dynamics of musical development of students; musical, semantic, artistic and performing analysis of works of art; comprehension of the artistic and figurative semantic content of the studied musical works; developing one's own interpretations of performed works; forecasting and critically reasoned evaluation of the results of one's activities, etc. An important point in the activities of a progressive music teacher, set up for creative, research quest, is his focus on the study and analysis of modern methods and technologies of music education, their creative refraction in accordance with the conditions of working with a particular children's group and more. O. Rebrova adds the readiness of the teacher to implement interdisciplinary, integrated, interactive programs and technologies that require not only a broad outlook, but also mental activity, developed, flexible, musical and scientific-pedagogical thinking ${ }^{2}$.

The problem of research orientation of educational activity in relation to the learning process in music-performing, vocal-performing and choir classes remains relevant. And this is no accident, because between the search for a studied material and the studying process, creation and implementation of the performer's own interpretation of a musical work, there are certain similarities. The research approach to work on a musical piece is manifested in the peculiarities of students' work on the study of the performed musical piece (equally this process can be defined as creative research): in considering the features of the historical period in which the authors worked, cultural life that surrounded them and influenced the formation of authors as artists, thinkers; in the ability to navigate in unfamiliar material, to bottom into the meaning encoded in the musical text, the content; in identifying patterns of structure, stylistic features of the work of art (A. Trifonov) ${ }^{3}$; in the analysis of musicalsemantic emotional and figurative content, in the process of which the

2 Реброва Е.Е. Научно-исследовательская подготовка будущих учителей музыки в условиях высшей школы. Традиции и новаторство в музыкальноэстетическом образовании. Москва : Флинта, 1999. С. 210-213.

3 Трифонов А.А. Диалектические методы познания как основной путь формирования профессионального мышления музыканта. Обучение $u$ воспитание учителя музыки на музыкально-педагогическом факультете педагогического института : сборник научных трудов. Куйбышев : КГПИ, 1980. C. 245-250. 
performer resorts to operations that are characteristic of the research activities of the scientist: analysis, ie the division of musical material into separate elements that retain all its features; to synthesis, building a holistic musical picture (O. Skripkina $)^{4}$; in the construction of the interpretive concept, performance hypotheses, which are realized in musical performance; in search of performing means and techniques that allow the most complete disclosure of the artistic idea of a musical work, to realize their creative performing interpretation, compared with the interpretations of other performers (V. Zhivov) ${ }^{5}$. The research orientation of students' activity is expressed in the fact that in the process of studying, mastering a musical work and preparing for the implementation of the performance plan in the process, they must not only botom into the artistic and semantic content of the work, but also model the desired impact of music on students and value the results of the work. This is facilitated by the student's knowledge of the age characteristics of musical perception, experience and opportunities of musical performance, the level of development of vocal-choral and performing-instrumental skills (to work on the mastering of vocal-choral and performance repertoire).

Thus, as noted earlier, in the modern innovative development of the entire system of domestic education in general and music in particular, the competence approach becomes a priority in the activities of teachers, including music teachers. It is this approach to the training of future music teachers that is most conducive to the education of professionals with not only a broad musical, pedagogical outlook, various ways of organizing musical activities of students, but also teachers who can identify problems and successfully overcome difficulties, develop their own technologies, approaches to music education, upbringing and development of students.

One of the strategic goals of introducing a competency-based approach to the whole process of pedagogical education is the formation of research competencies. Based on the proposed by T. Shkerina ${ }^{6}$

${ }^{4}$ Скрипкина Э.А. Развитие сознательности и эмоциональности в процессе работы над хоровым произведением в классе дирижирования. Bonpocbl хороведения на музыкально-педагогическом факультете. Москва : МГПИ, 1981. С. $103-107$.

5 Живов В.Л. Исполнительский анализ хорового произведения. Москва : Музыка, 1987. 95 с.

6 Шкерина Т.А. Исследовательская компетенция бакалавра - будущего педагога и условия ее развития. Психология обучения. 2010. № 11. С. 86-95. 
interpretation of the concept of "research competence" in relation to the professional training of music teachers, it can be considered as a general professional characteristic, expressed in the ability of future music teachers to perform pedagogical research, which is a set of knowledge of the main components, means and methods of conducting pedagogical research, relevant skills and willingness to implement them in practice in order to improve the music-educational process.

The introduction of interactive teaching methods is one of the important areas of improving the training of university students and a prerequisite for the effective implementation of the competency approach. The formation of the declared competencies involves the use of new technologies and forms of implementation of the educational process. First of all, there is an urgent need to move from informative forms and methods of organizing the educational process to active ones, reorientation from the knowledge approach to the activity one, search for opportunities to consolidate theoretical knowledge of educational subjects with their practical needs. The choice of modern educational technologies, active and interactive teaching methods should correlate with the competencies being formed.

Thus, now the system of professional music education faces the task not only of preserving the best traditions of music pedagogy, but also the generalization and implementation of the most effective interactive technologies. The use of interactive technologies is especially relevant in our time, when in connection with the Covid-19 pandemic, all educational institutions have become in distance learning.

\section{The use of interactive technologies in music education}

"Interactive" (inter - "mutual", act - "act") translated from English means the ability to interact. Thus interaction consists in stay of subjects of interaction in one educational and semantic space; joint immersion in solving cognitive tasks; consistency of choice of means and methods of realization of the set tasks; joint entry into a close field of emotional state, experience, involvement in the process of cognition ${ }^{7}$.

Interactive learning technologies have certain features, namely:

- focused on the activity approach (related to the creative, productive activities of the subject);

\footnotetext{
Інтерактивне навчання. URL: https://uk.wikipedia.org/wiki/ Інтерактивне_навчання.
} 
- reproduce the naturalistic concept of educational paradigm, which in contrast to the technocratic concept, which is based on the traditional form of learning, where the subject is a passive listener and performer of the teacher's demands, provides for the perception of the subject as a person who chooses his development, and the teacher only acts as a reference point;

- aimed at independent search for ways to solve a situation;

- have an unusual algorithm of actions and conditions of activity;

- ensure the active participation of all participants in the learning process;

- designed to create a comfortable, relaxed atmosphere of interaction;

- contribute to the departure from the "blind" translation of knowledge to the critical analysis of information and the generation of one's own position.

The use of modern learning technologies is one of the most important and sustainable trends in the world educational process. Of particular note in line with our study is a new direction that emerged in the late $\mathrm{XX}$ - early XXI century. It combines computerization and art and is called Digital Art. It involves the creation of works of art in digital form using computer programs. The development of Digital Art takes place in two directions: 1) the transfer of works of art in the digital environment; 2) creation of fundamentally new works with the use of computer technology. There are different types of Digital Art: digital painting, digital photography, hypertext literature, network art, interactive installations, game art, ASCII-art, pixel art, Chiptune, Demo scene, demo, digital poetry, etc.

Skills and abilities of application of information and communication technologies in the field of culture and art become more and more demanded, therefore urgency of use of interactive technologies in professional music education is caused by social need for increase of quality of training, practical need of application of modern computer programs in various educational institutions. Studies of domestic and foreign scientists convincingly prove not only the possibility and expediency of using interactive technologies in modern education, but also their special significance in the professional and personal development of students. Researchers of pedagogues-scientists also develop a wide range of pedagogical problems related to the involvement 
of students in the values of culture and art, increasing the level of their general cultural knowledge.

Peculiarities of the use of interactive technologies in various branches of modern music education are revealed in the works of $\mathrm{V}$. Zotova, A. Markov, I. Zabolotskaya, L. Romanenko, and others.

Thus, the researcher A. Markov proposed a model and algorithm for teaching the discipline "History of Performance" using information technology, formulated requirements for the level of teacher training not only in the profile of taught disciplines, but also for the level of training in computer science with characteristics and parameters of automated work places, with a developed system of methods of assessing the quality of teaching students in the disciplines of "History of Performance" using information technology ${ }^{8}$.

Researcher I. Zabolotska reveals the specifics of the development of musical hearing and thinking based on the use of computer programs based on the integration of logical-perceptual forms and independent activity. The author proves that as a result of independent work on the implementation of programs students form theoretical ideas and basic concepts of the discipline. Thus understanding of elements of musical language occurs by means of sensations and visual representations that in comparison with possibilities of verbal communication has more concrete, simple and dynamic nature of perception'.

Famous vocal coach V. Zotova (victoria-zotova.com) in her multivector author's method of vocal training uses interactive technologies, thanks to which her online lessons are intense and are the most effective.

In her work, the researcher relies on an alternative intensive technique EVT Dr. Joe Estill, which is based on research that helps optimize the learning process and its structure, develops creativity and communication of students and the ability to make non-standard independent decisions.

The use of music and computer technologies in the study of L. Romanenko allowed to establish that within the intersection of technoculture and music culture there is an opportunity to expand learning by integrating different fields of knowledge: music, sound design, computer science, culturology, art history, aesthetics,

8 Марков А.И. Педагогические условия использования информационных компьютерных технологий в музыкальном образовании : автореф. дис. ... канд. пед. наук. Ставрополь, 2004. 20 с.

9 Заболотская И.В. Новые информационные технологии в музыкальном образовании : автореф. дис. ... канд. пед. наук. Санкт-Петербург, 2000. 27 с. 
psychology, pedagogy, etc ${ }^{10}$. Music and computer technologies also allow to combine practical activities with various forms of music making (composition, vocal creativity, performance with the help of a musical computer, electronic musical instruments, etc.). Along with these traditional forms, we should also mention modern ones - DJing, working with remixes, working with covers and creating your own musical works in various genres (Rap, R\&B, Rock, beatbox, etc.).

Thus, we can conclude that in today's information world, such personal qualities as creativity and the ability to learn are extremely important for the successful work of a teacher. The use of interactive and information technologies is an effective support in the work of the teacher, because compared to the traditional form of teaching, the use of interactive technologies optimizes class time, which can be used to explain new material, practice skills, test knowledge, repeat material. The use of interactive technologies increases the effectiveness of learning, helps to realize the full potential of the individual - cognitive, moral and ethical, creative, communicative and aesthetic potentials, promotes the development of intelligence, increases the level of information culture.

The learning process using interactive technologies and multimedia is implemented on the basis of the following principles: clarity (use of illustrative material, video and audio material; increasing the level of students' learning the material); strength of knowledge acquisition (use of lessons-presentations and educational programs for repeating of educational material of previous lessons); scientific (use of materials from textbooks, articles, essays, research, monographs, encyclopedias, etc., with the possibility of their comparative analysis); accessibility (use of differentiated learning technology); systematic (application of presentations to develop a system of lessons); sequence (logic of construction and content of the educational process), which in turn contributes to the formation of research competence.

Thus, based on the analysis of scientific and methodological literature on music pedagogy, we can conclude that an important role in shaping the research competence of a music teacher belongs to the use of interactive and IT technologies.

10 Романенко Л.Ю. Музыкально-компьютерные технологии как феномен современной культуры : автореф. дис. ... канд. культурологии. Санкт-Петербург, 2015. 25 с. 
Speaking of pedagogical technologies in music education, we must take into account the definition of "educational computer technology", which introduced into scientific circulation S. Polozov: "a set of learning processes, where the main means of its intensification is the computer" 11 . According to the researcher, during computerized learning a special educational environment is formed, which arises as a result of interaction between a teacher, a computer and a student.

Educational computer technologies, i.e. in fact information and communication, provide an opportunity to maximally personalize the student's mode of operation in accordance with his temperament (character), psychophysiological characteristics of the body, talent, as well as efficiency. Their use in music education, on the one hand, is the result of general computerization of modern society, on the other - can significantly intensify teaching methods, in particular, update and integrate various areas of professional education: history and theory of music, sound design, arranging and instrumentation, perception and interpretation of musical text, technical means of teaching, pop vocal, vocal and vocal-instrumental ensembles, etc.

The term "music and computer technologies" proposed by researchers (I. Gorbunova, S. Puchkov, S. Filatov, etc.) is almost identical to the concept. Analysis of research interpretations of this concept shows that currently there is a reason to believe that there has formed a new interdisciplinary field of professional activity of the musician, associated with the creation and use of specialized music software and hardware that require professional knowledge and skills, both in music field and in the field of informatics.

Technologies are the subject of purposeful methodological study in many music educational institutions around the world. These are, for example, the Institut de Rechercheet Coordination Acoustique / Musique (IRCAM) and the Center d'Etudes Mathématiques et Automatique Musi cales (CEMAMu) in Paris; Stanford University Center for Computer Research in Music and Acoustics (CCRMA); San Diego Supercomputer Center (SDSC) of the University of California; research center of music and computer technologies of the Tchaikovsky Moscow State Conservatory, educational and methodical laboratory of music and computer technologies of the A. I. Herzen Russian State Pedagogical University.

11 Полозов С.П. Обучающие компьютерные технологии и музыкальное образование. Саратов : Изд-во Саратов. ун-та, 2002. 204 с. 
The global trend in the development of information and communication (computer) technologies in the field of music education is their demand in both professional and general education. A new educational and creative environment is being formed, the components of which are a computer and a software, in the depths of which new methods are being developed, focused on solving certain musical and pedagogical tasks.

Interactive information and communication technologies contribute to a fuller implementation of the didactic functions of teaching methods. In turn, the use of electronic educational resources contributes to the successful development of educational content, intensifies the process of developing the creative abilities of adolescents and students, because these age groups use gadgets as much as possible.

The computer opens wide opportunities for creative search. Various computer programs and electronic educational resources used in the process of vocal training, together have great pedagogical potential. Some of them act as a simulator, others - become an indispensable source of encyclopedic information (electronic library); are the means of controlling one's own artistic and performing activities; serve as a means of communication between a teacher and students, as well as between pupils / students themselves.

Acquaintance of students who study to play musical instruments, vocals or conducting with electronic educational resources that they should use in their professional activities, is due to the need to algorithmize their actions similar to the use of standard educational electronic resources (informational and cognitive entertainment programs and applications placed in Internet, various electronic devices, communicators, players, etc.). The basic difference is the purposefulness, rationality and effectiveness of this type of educational activity.

\section{IT technologies in music education}

Practice proves that the use of computer programs to intensify the process of music learning (vocal, instrumental, choral, etc.) of adolescents and students can solve various problems - to increase motivation to learn, optimize learning time by taking energy and timeconsuming issues, for example, to test the level of knowledge and skills with the help of various modules of knowledge testing and computer simulators.

The simplest electronic educational resources in terms of their mastery should include hypertext - electronic library, hypertext database, 
library of plug-ins (digitized vocal recordings). Their use can productively influence the process of professional development of a musician. In particular, various electronic libraries and hypertext databases are an interactive source of knowledge in the field of music and performing arts, which expands the student's horizons and logically influences the processes of creating the interpretation of a musical (vocal, instrumental, choral) work. Future musicians get acquainted with the historical, theoretical and artistic features of different styles and directions in vocal, instrumental and choral music, which allows them to realize their own performance more responsibly.

Electronic educational resources such as the music library play an important role. A wide selection, the ability to find and download notes also help to expand the professional capabilities of future music teachers.

The most productive is access to such an electronic resource as a library of plug-ins (digitized music recordings). The ability to quickly get an idea of the sound of a piece of music, analyze it, hear in different arrangements, as well as choose the optimal interpretation significantly optimizes the perception of students about the art of music.

The study of electronic educational resources related to the presentative type - various interactive textbooks and manuals (including videos), is mainly aimed at learning from the experience of prominent musicians and teachers who share their views on various types of music.

Specific video schools, video tutorials, media lessons (open lessons) posted on the Internet are of undoubted pedagogical value, as they "decipher" not only the standardized knowledge in the field of music, but also reveal, more often, the creative laboratory of an outstanding performer or world-renowned teacher, allow not only to join their creative search, to analyze specific executive or methodical instructions, but also to try to implement these instructions and recommendations in practice.

The experience of studying specific video schools, video tutorials, media lessons is very productive also because it helps to increase the motivational component of learning. Future music teachers not only strive to imitate outstanding performers, the secrets of whose skills they saw on a computer monitor, but also receive an additional stimulus for self-improvement in the chosen professional field.

The creative type of electronic educational resources includes various music editors, computer synthesizers (mixers), mobile applications for solo and ensemble singing, playing musical instruments, generators of backing track phonograms. 
Interactive music editors are convenient for creating your own music or arrangements when music is needed (for example, in ensemble work). Undoubtedly useful, as our practice shows, is the appeal of pupils / students to music editors not only to display in the form of a musical notation of their own works, but also to display on the notebook various trainings, exercises, intonation songs designed to improve their performing skills.

Computer synthesizers and generators of negative phonograms are a convenient and indispensable tool for accompanying one's own musicalperforming and educational activities of vocalists and instrumentalists, when it is necessary to receive a backing track phonograms in a short time if there is no access or impossibility to find it in electronic form library, notebook or interactive database.

Electronic educational resources related to the training type - vocal simulators, as well as various programs that diagnose pitch and purity of intonation - have local, narrowly practical character. They are aimed at improving the specific skills and abilities of vocalists.

The principle of work of vocal simulators is most productively realized in joint music-making when the pupil/student can choose for singing in ensemble of any singer from any country, to leave the application and to wait for the response. Such joint music-making carries an element of chance and additionally stimulates students to improve their own performing skills.

Finally, the most important for the productive work of a music teacher electronic educational resources are test resources: a virtual workshop, a blitz poll, a module of knowledge testing. Such resources contribute to the optimal assessment of both the general musical data of the student and his specific skills in a particular field of performance (instrumental, vocal, choral, theoretical, etc.). In particular, the virtual workshop helps to set tasks and solve them as quickly as possible, freeing up time for more detailed work on musical works.

The blitz-survey allows at intermediate stages to evaluate the professional perceptions of pupils/students, to determine the degree of adequacy of their understanding of different instructions of the teacher. Based on the results of the blitz survey, students have the opportunity to describe their performance, as well as, if necessary, adjust their creative aspirations.

The knowledge testing module is used to test the intellectual level of a student vocalist. The mechanism of such verification may include 
interactive answers to questions that are directly related to the specifics of the professional activities of each student vocalist.

Here are also some other features of the computer, mastering which is necessary for both the teacher-vocalist and for all students:

- recording, editing and printing scores;

- recording, editing and subsequent performance of scores using computer sound cards or external synthesizers connected via the MIDI interface;

- digitization of sounds, noises of different nature, and their further processing and conversion using sequencer programs;

- harmonization and arrangement of the finished melody with the use of selected musical styles and the ability to edit them until the invention of their own (styles);

- creating melodies on a so-called "random basis", by sequentially selecting musical sounds;

- control the sound of electronic instruments by entering certain parameters before performing;

- recording of parts of acoustic instruments and voice accompaniment in digital format with their subsequent storage and processing in sound editing programs;

- software synthesis of new sounds using mathematical algorithms;

- burning audio CDs, etc. ${ }^{12}$

The screen form of computer information allows joint observation and thinking about the facts, finding a way out of problematic learning situations, allows in the course of learning to discuss the relevance and significance of the research material. Research shows that the use of computers, namely specialized software, is a powerful stimulus for creative activity of students. Thus, the use of interactive technologies in the educational process, the capabilities of a video editor (in particular, Vegas Movie Studio) significantly expands the boundaries of perception of figurative and semantic content of musical works. At the same time, it greatly simplifies the process of working in the classroom with the search for the necessary tools, because the teacher "at hand" has all the necessary illustrative material, which he prepared in advance.

The main purpose of using modern multimedia technologies (for example, video editor Vegas Movie Studio) is to increase students'

12 Вішмиков М.П. Сучасні проблеми роботи 3 дитячими хоровими колективами. Культура України. 2016. Вип. 53. С. 89-99. 
motivation to study various musical disciplines. For example, in the process of mastering the topic "Complex three-part form" of the discipline "Analysis of musical works" the work can be organized as follows:

1) Students are given a definition of the terminological concept of "complex form" and offered differentiation into two- and three-part types; 2) with the help of a video editor Vegas Movie Studio to visual and auditory perception can offer a nocturne by F. Chopin op. 15 Fis-dur, a fragment from Borodin's opera "Prince Igor" - an aria by Khan Konchak, "Neapolitan Song" from "Children's Album" by P. Tchaikovsky; 3 ) comparing the proposed musical works, students characterize the features of the construction of 2 or 3-part complex form, highlight the characteristic typological parallels; 4) with the help of a video editor Vegas Movie Studio students work on the formative components of the genre diversity of music of the Baroque era, characterizing this historical period on the example of ancient variations of the XVII - first half of the XVIII century; 5) students compare musical genres (Pascal and Chacon), analyzing the characteristics of the construction of variational forms on the example of the fragment "Pascal and Fugue" for the organ in C minor by I. S. Bach and "Pascal" by G. Handel.

So, in our opinion, with the help of the Video Editor application, which belongs to the field of multimedia, you can solve the problems of visual learning, expand visualization in the presentation of educational material and apply in the educational process a number of new learning techniques: situational modeling, design of artistic perception, virtual reality, integrated and modular technologies, technology "package of situational tasks".

The use of software of information and communication technologies in the educational process allows the teacher to make level and profile differentiation; to individualize learning by mastering educational material at an individual pace in the presence of multilevel tasks; increase the amount of information received; to solve the problem of clarity of learning, to expand the possibilities of visualization of educational material; to intensify independent educational and cognitive activity of students; to carry out independent educational and research activities; create a comfortable, optimal learning environment ${ }^{13}$.

13 Коняхина М.С. Особенности интерактивных технологий в организации процесса художественного восприятия студентов. Образование в глобальном мире: инновации, проблемь и перспективы. Москва ; Берлин : Директ-Медиа, 2018. C. 80-85. 
Thus, based on the analysis of scientific and methodological literature, scientific research of domestic and foreign scientists, our own practical experience, we can offer the following types of interactive technologies used in music lessons and contribute to the formation and development of research competence of future music teachers during distance learning and conducting online classes:

1. The interactive technological method of situational modeling is based on the principle of game learning (as an effective communication activity) in the format of small groups, where the distribution of "roles" between students is made for speed and accuracy in determining the form of music and its content.

2. Interactive technological method of designing artistic perception covers the structural and holistic process of perception (from the disclosure of the idea laid down by the composer in the work to its translation upon the artistic content level). This technique is important for the descriptive and verbal characteristics of works.

3. Interactive technological method of mastering virtual reality involves the use of all participants in the educational process of information and educational resources, distance learning technologies and more. Thus, projects created by students can be used as a final product for educational and teaching purposes. The use of integrated and interactive technologies is necessary in view of conducting individual lessons in all musical disciplines. This aspect implies personal-activity and competence approaches in education, which are implemented in the system of professional training of a musician-performer (instrumentalist, vocalist, conductor) and musician-theorist.

4. Interactive technological technique "package of situational tasks" is aimed at the application of problem-situational analysis of specific cases (tasks-situations). The "package of situational tasks" offered by the teacher develops in students the ability to work out a problem of creating (or reproducing) the composition of a musical work (instrumental, vocal or choral), find solutions to determine the thematic content, formation, forms the necessary algorithms and schemes of understanding and perception the musical piece.

5. Interactive modular technology implies programmed learning. Depending on the nature of the curriculum, the following learning models are used: linear program (B. Skinner's operant training), branched program (N. Crowder), mixed program (Sheffield, Warsaw 
methods $)^{14}$. The teacher creates a theoretical and practical basis for conducting both lectures and individual practice-oriented classes to determine the level of mastering the material. The practical basis can be represented by an algorithmic map, abstracts, where the theoretical material is summarized, test tasks, etc. Thanks to the modular technology, the teacher has the opportunity to quickly monitor the activities of students, to exercise control over their independent work, thus obtaining a quality end product in the form of analytical work.

\section{CONCLUSIONS}

Thus, based on all the above mentioned, we can conclude that the use of interactive-information and communication technologies involves improving the quality of education in general and music in particular, where the breadth and clarity of material contributes to the speed of information assimilation, and meets the perceptions of modern students. The essence of interactive learning technologies is not a contradictory dialogue, but, on the contrary - the teacher and the student communicate in maximum interaction.

Introduction of interactive forms of education is one of the most important areas of improving the training of future music teachers in the modern educational space. The value of interactive learning is that the learning process is organized in such a way that all participants are involved in the process of scientific knowledge, have the opportunity to understand and reflect on what they know, think and can do. The joint activity of the pupil/student and the teacher in the process of research activity is manifested in the fact that everyone makes a special individual contribution, there is an exchange of knowledge, scientific ideas, methods of activity.

Analysis of the use of modern interactive learning technologies in the educational process and our own practical experience allowed us to identify priority areas for improving the quality of music education and identify the most effective interactive teaching methods that will contribute to the formation of research competence of future musicians. These include situational modeling, design of artistic perception, virtual reality, integrated and modular technologies, technology "package of situational tasks".

14 Перспективы программированного обучения / К. Томас, Дж. Девис, Д. Опеншоу, Дж. Берд. ; пер. с англ. О.А. Бондина, Н.Т. Кобяковой. Москва : Мир, 1966. 247 с. 
The considered interactive technologies can be transformed by the teacher into any educational platform that will allow him to be modern and mobile.

Modern educational institutions can no longer be imagined without innovative programs and teaching methods, relevant technical means that affect the organization of the educational process and the formation of the student's personality. Educational institutions cannot exist outside of scientific and technological progress, and children, adolescents and students are the most active connoisseurs and consumers of the IT product in society.

\section{SUMMARY}

The current stage of changes in the economic, political, social and cultural life of society is marked by the strengthening of the role of education, in line with the problem of improving the quality of training associated with new requirements for the educational system designed to shape the individual. Given that the modern specialist has to solve problems that had no analogues in the past, and this requires the formation of analytical, informational, reflective, perceptual, communicative and other skills, it becomes important to develop a system of training a competent specialist who knows the basics of pedagogical skill and creativity and operates freely with them competence approach in education is associated with personalityoriented and activity-based approaches to learning, because, on the one hand, it concerns the student's personality, and on the other hand, it can be implemented and tested only in the course of a particular student.

Therefore, the competency approach involves transforming, first of all, the content of education, transforming it from a model that exists objectively, for "all" students, to the subjective achievements of one student, which can be measured. The research competence of a music teacher can be defined as a set of interrelated personality traits, which involves the perfect formation of theoretical and practical skills, the ability to apply them in professional activities, the ability to creatively and unconventionally solve problems, be responsible for their work and professional growth. through constant self-development, selfimprovement and self-education.

One of the effective and relevant ways to develop the professional competence of a music teacher in general and research competence in particular is interactive technologies. 
Analysis of current scientific and methodological literature and dissertation research on music pedagogy and vocal education has shown that an important role in shaping the research competence of a music teacher is played by the use of IT-technologies - a set of learning processes, educational environment that arises as a result of interaction between teacher, computer and student, which is especially relevant today in terms of distance learning.

Due to the introduction of distance learning in the educational process, a new interdisciplinary field of professional activity of the musician, associated with the creation and use of specialized music software and hardware that require professional knowledge and skills, both in music and acting, and in the field of educational management, information and computer technologies, etc.

\section{References}

1. Арчажникова Л.Г. Профессия - учитель музыки. Москва : Просвещение, 1984. $111 \mathrm{c.}$

2. Реброва Е.Е. Научно-исследовательская подготовка будущих учителей музыки в условиях высшей школы. Традиции $u$ новаторство в музыкально-эстетическом образовании. Москва : Флинта, 1999. С. 210-213.

3. Трифонов А.А. Диалектические методы познания как основной путь формирования профессионального мышления музыканта. Обучение и воспитание учителя музыки на музыкальнопедагогическом факультете педагогического института : сборник научных трудов. Куйбышев : КГПИ, 1980. С. 245-250.

4. Скрипкина Э.А. Развитие сознательности и эмоциональности в процессе работы над хоровым произведением в классе дирижирования. Вопросы хороведения на музыкальнопедагогическом факультете. Москва : МГПИ, 1981. С. 103-107.

5. Живов В.Л. Исполнительский анализ хорового произведения. Москва : Музыка, 1987. 95 с.

6. Шкерина Т.А. Исследовательская компетенция бакалавра будущего педагога и условия ее развития. Психология обучения. 2010. № 11. С. 86-95.

7. Інтерактивне навчання. URL: https://uk.wikipedia.org/wiki/ Інтерактивне_навчання.

8. Марков А.И. Педагогические условия использования информационных компьютерных технологий в музыкальном образовании : автореф. дис.... канд. пед. наук. Ставрополь, 2004. 20 с. 
9. Заболотская И.В. Новые информационные технологии в музыкальном образовании : автореф. дис.... канд. пед. наук. СанктПетербург, 2000. 27 с.

10.Романенко Л.Ю. Музыкально-компьютерные технологии как феномен современной культуры : автореф. дис. ... канд. культурологии. Санкт-Петербург, 2015. 25 с.

11.Полозов С.П. Обучающие компьютерные технологии и музыкальное образование. Саратов : Изд-во Саратов. ун-та, 2002. 204 c.

12.Вішмиков М.П. Сучасні проблеми роботи 3 дитячими хоровими колективами. Культура Украӥни. 2016. Вип. 53. С. 89-99.

13.Коняхина М.С. Особенности интерактивных технологий в организации процесса художественного восприятия студентов. Образование в глобальном мире: инноващии, проблемь и перспективы. Москва ; Берлин : Директ-Медиа, 2018. С. 80-85.

14.Перспективы программированного обучения / К. Томас, Дж. Девис, Д. Опеншоу, Дж. Берд. ; пер. с англ. О.А. Бондина, Н.Т. Кобяковой. Москва : Мир, 1966. 247 с.

\section{Information about the authors: Kulikova S. V.,}

Candidate of Pedagogical Sciences, Associate Professor, Associate Professor at the Department of Music Art and Methods of Music Education Volodymyr Vynnychenko Central Ukrainian State Pedagogical University 1, Shevchenko str., Kropyvnytskyi, 25006, Ukraine

Zotova V. E., Postgraduate Student at the Faculty of Arts named after A. T. Avdievsky National Pedagogical Dragomanov University 9, Pyrohova str., Kyiv, 01601, Ukraine 